\title{
Lack of Virus Transmission from Bovine Viral Diarrhoea Virus Infected Calves to Susceptible Peers
}

\author{
By R. Niskanen ${ }^{1}$, A. Lindberg ${ }^{2}$, B. Larsson ${ }^{3}$ and S. Alenius ${ }^{4}$ \\ ${ }^{1}$ Department of Ruminant Medicine and Veterinary Epidemiology, Swedish University of Agricultural Sciences, \\ ${ }^{2}$ Swedish Dairy Association, Research and Development, ${ }^{3}$ Swedish Board of Agriculture, Jönköping, and ${ }^{4}$ De- \\ partment of Ruminant and Swine Diseases, National Veterinary Institute, Uppsala, Sweden.
}

\begin{abstract}
Niskanen R, Lindberg A, Larsson B, Alenius S: Lack of virus transmission from Bovine Viral Diarrhoea Virus infected calves to susceptible peers. Acta vet. scand. 2000, 41, 93-99. - None of 14 calves not previously exposed to BVDV became infected after being forced to have nose-to-nose contact with a group of 5 calves primarily infected with BVDV. These were 5 male calves primarily infected with a type I BVDV strain, after nose-to-nose contact with a persistently viraemic calf. All 5 became infected and were clinically affected. They were slightly depressed and pyretic at 8-9 days postinfection, with a body temperature of up to $41.6^{\circ} \mathrm{C}$, but no medical treatment was required. Seroconversions to BVDV were detected in these calves at 14 to 21 days postinfection. The 14 healthy calves, proved to be free from BVD virus - as well as antibodies, were introduced 2 by 2 into the group of 5 primarily infected calves on days $4,7,14,21,28,35$ and 42 after the 5 calves had been in contact with the persistently BVDV-infected calf. Each pair of calves stayed within the primarily infected group for 2 days. None of these 14 calves seroconverted to BVDV.
\end{abstract}

primary infection; persistent infection; infectivity; BVDV; pestivirus.

\section{Introduction}

Animals persistently infected (PI) with BVDV are considered to be the most effective transmitters of the infection. The main route of viral transmission is by direct contact between such constantly viraemic individuals and susceptible cattle (Roeder \& Harkness 1986).

Primary BVDV-infected cattle are also potential virus transmitters, as they do have a period of viraemia, even though short and transient (Meyling et al. 1990). Furthermore, they do shed BVDV in most secretions during the course of infection. The concentrations of virus in such secretions are however substantially lower than in similar fluids from PI animals (Brownlie et al. 1987, Meyling et al. 1990, Bruschke 1998).

Reports regarding the infectivity associated with primary BVDV infection differ. When animals were experimentally infected by insemination, by parenteral injection, and by rectal examination, there was no transmission of the infection to susceptible in-contact animals (Pritchard 1963, Meyling \& Jensen 1988, Lang-Ree et al. 1994). On the other hand, seroconversions have been reported to occur in closed groups of cattle in the absence of persistently infected animals. Anyway, such circulation of the virus seems to be restricted to large populations (Brownlie et al. 1987, Meyling et al. 1990, Moerman et al. 1993).

Systematic eradication of BVDV without vaccination started in Scandinavia in 1993 (Lindberg \& Alenius 1999). Generally speaking, the herd clearance procedures used rely on the as- 
sumption that the main route of transmission is one-way, from PI animals to susceptible animals. This assumption conflicts with studies reporting transient infections that circulate for a long period of time, 10 months or more, even in the absence of PI animals (Barber et al. 1985, Moerman et al. 1993, Edwards 1997).

Susceptible herds seem to become infected with BVDV mainly by introduction of PI animals or of antibody positive pregnant animals carrying a PI foetus (Houe \& Palfi 1993, Meyling et al. 1990). Even though these are the main routes, the risk of spreading the infection via primary infected animals cannot be excluded, at least in a control scheme context. One measure included in the Swedish BVDV scheme regulations which is intended to prevent the spread of infection via this route is repeated testing for antibodies under quarantine conditions, which animals from non-certified herds have to undergo before they are introduced into a BVDV scheme herd (Alenius et al. 1997).

In conclusion, there are contradictory reports regarding the infectivity associated with primary BVDV infection. In order to provide adequate risk management in a scheme context, the nature of the primary infection needs to be studied further. That is why the present trial was designed to study the transmission of BVDV from primary infected calves to susceptible in-contact animals at different times post-infection.

\section{Materials and methods}

Animals, housing and biosecurity measures

Eigthteen male calves and one female calf, 13 of Swedish Red and White breed and 6 Friesians were obtained from a closed dairy herd. The herd was certified free from BVDV infection within the framework of the Swedish control scheme on BVDV (Alenius et al. 1997).

The calves, aged between 55 and 124 days on arrival at the clinic, were housed in isolation for one month prior to the experimental infection. This was done in order to avoid stress effects due to transportation and change of environment. Five male calves were housed together in an isolated pen and the other 14 calves were placed in individual pens, with 2 pens in each of 7 isolated cowsheds. All calves proved to be free from BVD virus and antibodies prior to the trial. During the trial, all persons in contact with the calves changed their coats and boots and put on disposable gloves before entering each cowshed.

On arrival, the calves showed mild symptoms from the upper respiratory tract, with slightly reddened nasal mucos membranes, serous nasal and conjunctival discharge and intermittent dry cough. Two of the calves were treated with antibiotics before the trial started. These symptoms were then observed intermittently throughout the experiment.

\section{Virus source}

The source of the virus was a persistently infected and clinically healthy 6-month-old Charolais-crossbred calf, which was obtained from a 20-cow beef cattle herd. This had been identified as being BVDV-infected, according to the definition of the Swedish control scheme on BVDV. A non-cytopathogenic field strain of BVDV was isolated from the calf's blood on 2 occasions, 2 months apart, while the calf remained seronegative. Thus, the calf was confirmed as being persistently infected (PI) with BVDV. The virus was shown to be a type I BVDV strain, by using a polymerase chain reaction technique and sequencing (Vilcek et al. 1998).

\section{Experimental design}

The trial was initiated by forcing 5 male calves in nose-to-nose contact with the persistently BVDV viraemic calf (day 0 ). This calf stayed within the group for $6 \mathrm{~h}$ and was thereafter re- 
moved and slaughtered. The 5 in-contact animals were then moved back to their own isolated pen. At 4, 7, 14, 21, 28, 35 and 42 days after contact with the viraemic calf, a new pair of calves not previously exposed to BVDV, was introduced to the 5 calves. The susceptible calves were forced to have nose-to-nose contact with all calves in the infected group at the time of introduction as well as at removal. Each pair of calves stayed in the group for 2 days and were then moved back to their own pens.

\section{Blood sampling}

Serum samples were collected from each of the 5 primary BVDV-infected calves on days 0,4 , $7,14,21,28,35$ and 42 after contact with the persistently BVDV-infected calf. Serum samples were also collected weekly from the 14 incontact calves during a 4-week period after they had been in contact with the 5 primarily BVDVinfected calves.

EDTA blood samples for haematology were collected from each of the 5 transiently BVDVinfected calves on days 0,7 and 14 after their contact with the PI calf.

\section{Recording of clinical symptoms}

The following parameters were recorded daily: body temperature, general condition, consistency of faeces and presence of cough. Furthermore, examination of heart and respiratory rate, respiratory sound auscultation, registration of conjunctival and nasal discharge and inspection of the mucous membranes of the mouth and muzzle were all performed in connection with each blood sampling.

\section{Detection of antibodies to BVDV, bovine} corona-, bovine respiratory syncytial-, and bovine para-influenza-3 virus and isolation and detection of $B V D V$

Indirect enzyme-linked immunosorbent assays (ELISAs) (SVANOVA; Uppsala, Sweden) were
Table 1: Identification chart of 5 male calves infected with BVDV by nose-to-nose contact with the persistently viraemic calf. The calves were between 140 and 150 days old at exposure.

\begin{tabular}{llcc}
\hline $\begin{array}{l}\text { Calf } \\
\text { no. }\end{array}$ & Breed & $\begin{array}{c}\text { Body tempera- } \\
\text { ture }\left({ }^{\circ} \mathrm{C}\right) \\
\text { maximum } \\
\text { (at day }^{2} \text { ) }\end{array}$ & $\begin{array}{c}\text { Sero- } \\
\text { conversion } \\
\text { detected } \\
\text { on day }^{2}\end{array}$ \\
\hline 1 & SRB $^{1}$ & $41.0(9)$ & 14 \\
2 & SRB $_{3}$ & $41.6(8)$ & 21 \\
4 & Friesian & $41.4(8)$ & 14 \\
5 & SRB & $40.4(8)$ & 14 \\
\hline
\end{tabular}

${ }^{1}$ Swedish Red and White breed

${ }^{2}$ Day post exposure

used to determine seroconversions to BVDV, bovine corona-, bovine respiratory syncytial-, and bovine para-influenza-3 virus, as described by Graham et al. (1997). The presence of BVDV in serum was detected by an immunoperoxidase test (Meyling 1984). All virological analyses were performed at the National Veterinary Institute, Uppsala.

\section{Haematological examinations}

The total number of leukocytes and the total number of platelets were determined in EDTA preserved blood samples using an electronic counter (Sysmex F-800, Toa Medical Electronics Co, Kobe, Japan). Differential leukocyte counts, were performed under a light microscope, using smears stained with MayGrünewald Giemsa's solutions. Analyses were performed at the Department of Clinical Chemistry, Swedish University of Agricultural Sciences, Uppsala.

\section{Results}

At 8-9 days post-infection (dpi), all 5 calves in the primary infected group had slightly depressed general conditions. They lay down more than usual, and were pyretic with a body 


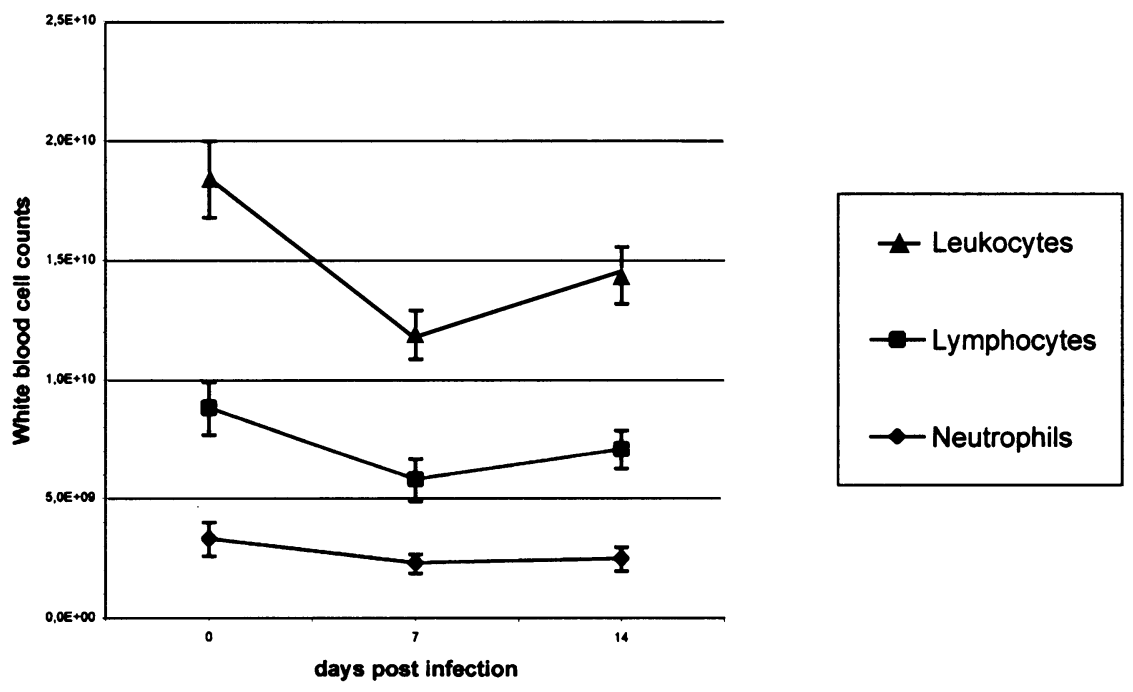

Figure 1: Mean white blood cells counts, with standard deviations, for 5 calves transiently infected with BVDV.

temperature of up to $41.6^{\circ} \mathrm{C}$. Despite the fever, their appetite remained unaffected. No other symptoms of infection were observed and no medical treatment was required (Table 1).

A decrease in the mean total counts of leukocytes was seen at $7 \mathrm{dpi}$, which in the differential count proved to be the result of a decrease in neutrophils and lymphocytes. At $14 \mathrm{dpi}$, the mean white blood cell counts had increased, but were still below the original levels at day 0 (Fig. 1). No differences were observed in platelet counts. The calves seroconverted to BVDV on 14 to 21 dpi (Table 1 ).

None of the other 14 calves seroconverted to BVDV. During the month prior to the trial, one of them seroconverted to bovine para-influenza-3 virus, but this infection could not be observed clinically. The 2 calves introduced into the group of the 5 primarily BVDV-infected calves at $42 \mathrm{dpi}$, were medically treated as they became moderately debilitated, with respiratory affection and fever (up to $40.7^{\circ} \mathrm{C}$ ) 1 to 3 days after the contact.
Throughout the experiment, all 19 calves remained seronegative to bovine coronavirus and to bovine respiratory syncytial virus.

The growth rate was about $1 \mathrm{~kg}$ per day for all 19 calves while housed at the Clinic.

\section{Discussion}

None of 14 calves seroconverted to BVDV after being forced to have close contact with the 5 calves that were transiently infected with the virus. The results are consistent with those in previously published studies which indicate a low degree of transmissibility from primarily infected cattle to susceptible in-contact animals. Furthermore, it supports the perception of BVDV epidemiology on which the Swedish control scheme is based, i.e. that transiently infected animals are, compared with PI animals, rather ineffective in transmitting the virus. Rather, the main spread within infected herds seems to occur during periods when there are PI animals present (Lindberg \& Alenius 1999).

Two factors which may influence the infectivity 
associated with the primary infection are: variation in duration of viraemia, and the concentration of virus in excretions. Primary infected calves have been shown to have considerably varying concentrations of virus in serum, between 2 and 63 and even up to 106.9 TCID $_{50}$ per ml (Kirkland et al. 1991; Bolin \& Ridpath 1992). These differences may be both strainand host-associated. For example, animals infected with type 2 BVDV strains can have higher concentrations of virus in serum and a longer duration of viraemia (Bruschke 1998). The infectivity can vary between strains of the virus if there are differences in replication and virulence. Host factors that can influence the infectivity are suppressive factors such as environmental stress, poor nutritional status, poor immunological status, e.g. due to inadequate colostrum intake and/or concurrent disease. Such factors can also affect the susceptibility in non-infected animals. Therefore, if such conditions are present, primary infected animals may play a more significant role in the spread of BVDV infection than in this experiment.

All 5 calves initially exposed by nose to nose contact with a calf persistently infected with a non-cytopathogenic field strain of BVDV type I became viraemic and seroconverted. The tranmission of the virus was clinically indicated by signs of illness and was subsequently confirmed 14 to 21 days post-contact by detection of antibodies to BVDV. As could be expected, based on earlier observations and experimental studies (Baker 1987, Tråvén et al. 1991), the calves showed only mild clinical symptoms following the primary BVDV infection, viz. fever and slight depression for one day. As there was no evidence of poor appetite, the signs of illness may have remained unobserved under field conditions.

Although postnatal primary infections with BVDV type 1 strains are most often subclinical, affected animals may show fever, lesions on the mucosal membranes, poor appetite, lameness, diarrhoea, or cough (for a review, see van Oirschot 1983). Factors that may have influenced the clinical outcome in this study are, for example, the virus strain and the fact that environmental, nutritional or management stresses were not present to exacerbate the effects of the infection. Furthermore, only one seroconversion to other bovine viruses tested for was detected during the entire observation period. Under natural farming conditions, other common bovine respiratory or enteric pathogens may be present to a larger extent and interaction with co-infecting agents may exacerbate the symptoms.

To sum up - BVDV was effectively transmitted by nose-to-nose contact from a persistently BVDV viraemic calf to 5 male calves not previously exposed to BVDV, whereas calves in close contact with the 5 primary infected calves did not become infected. From these results we conclude that primary infected animals seem to be poor transmitters of BVDV infection. Nevertheless, our knowledge about transmission of BVDV from primary infected calves is still limited and further experiments and field studies are therefore needed, such as investigating the effect of concurrent infection(s) on the spread of BVDV infection from primary infected cattle.

\section{Acknowledgements}

We express our thanks to Mrs Maj Hjort and Mrs Maja Persson for excellent technical assistance. We also thank Ms Liselotte Forsberg for taking such a good care of the calves during the study. This work was supported by grants from Swedish Farmer's Foundation for Agricultural Research.

\section{References}

Alenius S, Lindberg A, Larsson B: A national approach to the control of bovine viral diarrhoea virus. In: Edwards S, Paton DJ, Wensvoort G (eds.): 
Proceedings of the $3^{\text {rd }}$ ESVV Symposium on Pestivirus Infections, Lelystad, The Netherlands, 1920 September 1996. DLO Institute for Animal Science and Health, 1997, pp. 162-169.

Baker JC: Bovine viral diarrhea virus: A review. J. Am. Vet. Med. Ass. 1987, 190, 1449-1458.

Barber DML, Nettleton PF, Herring JA: Disease in a dairy herd associated with the introduction and spread of bovine virus diarrhoea virus. Vet. Rec. 1985, 117, 459-464.

Bolin SR, Ridpath JF: Differences in virulence between two noncytopathic bovine viral diarrhea viruses in calves. Am. J. Vet. Res. 1992, 53, 2157-2163.

Brownlie J, Clarke MC, Howard CJ, Pocock DH: Pathogenesis and epidemiology of bovine virus diarrhoea virus infection of cattle. Annls. rech. vét. 1987, 18, 157-166.

Bruschke C: Pathogenesis and vaccinology of BVDV infections. Thesis. 1998. DLO Institute for Animal Science and Health, Lelystadt, The Netherlands. 119. pp.

Edwards $S$ : Observations of bovine viral diarrhoea virus infection in dairy herds, and the response to different control strategies. In: Edwards, S., Paton, D.J. and Wensvoort, G. (eds.): Proceedings of the $3^{\text {rd }}$ ESVV Symposium on Pestivirus Infections, Lelystad, The Netherlands, 19-20 September 1996, DLO Institute for Animal Science and Health, 1997, pp. 173-176.

Graham DA, Mawhinney KA, McShane J, Connor TJ, Adair BM, Merza M: Standardization of enzyme-linked immunosorbent assays (ELISAs) for quantitative estimation of antibodies specific for infectious bovine rhinotracheitis virus, respiratory syncytial virus, parainfluenza-3 virus, and bovine viral diarrhoea virus. J. Vet. Diagn. Invest. 1997, 9, 24-31.

Houe H, Palfi V: Estimation of herd incidence of infection with bovine virus diarrhoea virus (BVDV) in herds previously without animals persistently infected with BVDV. Acta vet. Scand. 1993, 34, 133-137

Kirkland PD, Richards SG, Rothwell JT, Stanley DF: Replication of bovine viral diarrhoea virus in the bovine reproductive tract and excretion of virus in semen during acute and chronic infections. Vet. Rec. 1991, 128, 587-590.

Lang-Ree JR, Vatn T, Kommisrud E, Løken T: Transmission of bovine viral diarrhoea virus by rectal examination. Vet. Rec. 1994, 135, 412-413.

Lindberg A, Alenius S: Principles for eradication of bovine viral diarrhoea virus (BVDV) infections in cattle populations. Vet. Micr.1999, 64, 197222.

Meyling A: Detection of BVD virus in viremic cattle by an indirect immunoperoxidase technique. In: McNulty MS, MacFerran JB (eds): Recent Advances in Virus Diagnosis. Martinus Nijhoff Publishers, The Hague, 1984, pp. 37-46.

Meyling A, Houe H, Jensen AM: Epidemiology of bovine virus diarrhoea virus. Rev. Sci. Tech. Off. Int. Epiz. 1990, 9, 75-93.

Meyling A, Jensen AM: Transmission of bovine virus diarrhoea virus (BVDV) by artificial insemination (AI) with semen from a persistently infected bull. Vet. Microbiol. 1988, 17, 97-105.

Moerman A, Straver PJ, de Jong MCM, Quak J, Baanvinger Th, van Oirschot JT: A long-term epidemiological study of bovine viral diarrhoea infections in a large herd of dairy cattle. Vet. Rec. 1993, 132, 622-626.

Pritchard WR: The bovine viral diarrhea-mucosal disease complex. In: Brandley CA, Jungherr EL (eds): Advances in Veterinary Science. Academic Press, New York, 1963, 1-47.

Roeder PL, Harkness JW: BVD virus infection: Prospects for control. Vet. Rec. 1986, 118, 143-147.

Tråvén M, Alenius $S$, Fossum C, Larsson B: Primary bovine viral diarrhoea virus infection in calves following direct contact with persistently viraemic calf. J. Vet. Med. B 1991, 38, 453-462.

Van Oirschot JT: Congenital infections with nonarboviruses. Vet. Microbiol. 1983, 8, 321-361.

Vilcek S, Alenius $S$, Paton DJ, Belák S: Genetic clustering of bovine viral diarrhoea viruses in cattle farms. Vet. J. 1999, 1, 33-8.

\section{Sammanfattning}

Utebliven smittöverföring av Bovint virus diarrévirus trots direkt kontakt mellan primärt infekterade och mottagliga kalvar.

Ingen av 14 seronegativa kalvar, som sattes i kontakt med en grupp kalvar primärinfekterade med BVDV, blev smittade med detta virus. Den primärinfekterade gruppen bestod av 5 jämngamla tjurkalvar som infekterades med BVDV genom att tvingas till nos mot nos kontakt med en persistent viremisk kalv. Samtliga 5 kalvar blev smittade med BVDV. De hade 8 till 9 dagar efter smittillfället lindrigt nedsatta allmäntillstånd och feber upp till $41.6^{\circ} \mathrm{C}$. Dock behövde inga medicinska behandlingar genomföras. 
Antikroppar kunde påvisas i serum från och med 14 till 21 dagar efter smittillfället. Fjorton friska BVDVnegativa och seronegativa kalvar introducerades, 2 och 2 , in i gruppen av primärinfekterade kalvar dag $4,7,14,21,28,35$ och 42 efter gruppens kontakt med den persistent viremiska kalven. Varje par kalvar stannade i gruppen 2 dagar och tvingades till nos mot nos kontakt med alla de primärinfekterade kalvarna. Ingen av dessa 14 kalvar serokonverterade mot BVDV.

(Received April 19, 1999; accepted January 14, 2000).

Reprints may be obtained from: R. Niskanen, Department of Ruminant Medicine and Veterinary Epidemiology, Swedish University of Agricultural Sciences, P.O. Box 7019, SE-750 07 Uppsala, Sweden. E-mail: Rauni.Niskanen@idmed.slu.se, tel: +46(0) 18 672895, fax: +46 (0) 18673545. 